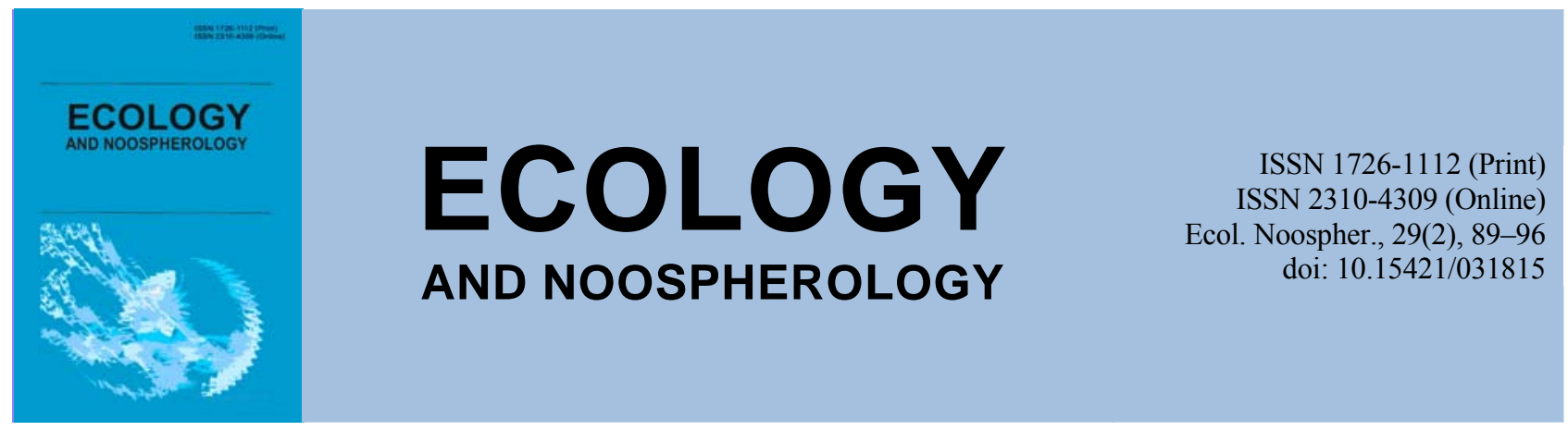

\title{
Environmental evaluation of remediated lands quality of manganese quarry lands (Zaporizhsky and Olexandrovsky opencast workings) on humus content and salinity
}

\author{
I. M. Loza, O. Y. Pakhomov
}

Oles Honchar Dnipro National University, Dnipro, Ukraine

Article info

Received 29.10.2018

Received in revised form 05.11 .2018

Accepted 08.11.2018

Oles Honchar Dnipro

National University

Gagarin Ave., 72, Dnipro, 49010, Ukraine.

Tel.: +38-095-230-85-29

E-mail: irinaloza23@gmail.com

Loza, I. M., \& Pakhomov, O. Y. (2018). Environmental evaluation of remediated lands quality of manganese quarry lands (Zaporizhsky and Olexandrovsky opencast workings) on humus content and salinity. Ecology and Noospherology, 29(2), 89-96. doi:10.15421/031815

Environmental protection, rational use of natural resources and ensuring the ecological safety of human life are integral conditions of sustainable economic and social development of European Union. Mining industry is one of the powerful factors that leads to degradation of various native landscapes. Withdrawal of agricultural land from intended use results from the minerals extraction. Instead them man-made landscapes (dumps and quarries) are formed, as well as destructive territories characterized by subsidence, contamination with toxic compounds, decrease of species richness and biological diversity. Disturbed territories formed during mining process are usually partially restored with remediation. Remediation process consist of two stages: technical and biological. In the result of technical stage implementation, substrates with different potential fertility having different environmental properties and quality are formed. However, in quality assessment of remediated soils insufficient attention is paid to restoration of the soil environmental properties, namely their suitability for existence of soil biota, which ensures the soil sustainability and vitality. Purpose of the presented work was to assess quality of remediated lands in condition of Ordzhonikidzevsky manganese quarry (Olexandrovskiy and Zaporizhkiy careers) on the possibility of their use and suitability for soil biota existence, as well as providing recommendations for further rational economic use of them. Data on chemical properties of reclaimed soil were collected on the sites of performed recultivation. Humus content was determined according to DSTU 4289: 2004, analysis of water extraction was carried out according to GOST 26425-85, GOST 26426-85, GOST 26427-85, GOST 26428-85. The study is novel in that it is proposed to take into account environmental conditions for existence of soil invertebrates which play a crucial role in formation of agro-system stability mechanisms. The main indicators determining the productivity of remediated lands and the degree of their suitability for soil biota existence are values of actual acidity and salinity degree. An assessment of the reclaimed lands quality on the Ordzhonikidzevsky ore mining and processing enterprise was carried out on the example of Zaporizhsky and Olexandrovsky opencast workings on the possibility of their economic use and suitability for the soil biota existence, as well as recommendations for further rational use. It was found that studied areas by the main characteristics are suitable for the further settlement and successful existence of soil biota. It is concluded that as a result of the technical stage of reclamation, an artificial reclaimed soil was obtained, which, according to the main characteristics, is similar to native zonal soils located in this area prior to mining; the recultivated soil has somewhat less fertility and greater salinity of lower horizons, but it is able to perform ecological functions and can not only be used for economic purposes, but also perform ecological role, serving as an environment for existence of soil invertebrates.

Keywords: remediated soil quality; salinity; mining industry; ecosystem assessment; technogenesis; soil invertebrates

\section{Екологічне оцінювання якості рекультивації земель Олександрівського та Запорізького кар'єрів видобутку марганцевої руди щодо вмісту гумусу та водорозчинних солей}




\section{I. М. Лоза, О. Є. Пахомов}

Дніпровський національний університет імені Олеся Гончара, Дніпро, Україна

Охорона навколишнього середовища, раціональне використання природних ресурсів та забезпечення екологічної безпеки життєдіяльності людини - невід'ємні умови сталого економічного та соціального розвитку європейських держав. Одним із потужних чинників, що призводить до деградації різних природних ландшафтів, $\epsilon$ діяльність видобувної промисловості. У результаті видобутку корисних копалин з використання вилучаються землі господарського призначення. На їх місці формуються техногенні ландшафти (відвали і кар'єри), а також деструктивні території, для яких характерні просідні явища, забруднення токсичними сполуками, зниження видового багатства і біологічного різноманіття угруповань таких ділянок. Порушені території, утворені в процесі вуглевидобутку, частково відновлюють шляхом рекультивації, під час якої використовують субстрати з різною потенційною родючістю, що мають різні екологічні властивості та якість. Збір даних щодо властивостей рекультивованих земель здійснювали по ділянках виконаної рекультивації. Вміст гумусу визначали за ДСТУ 4289:2004, аналіз водної витяжки проводили згідно з ГОСТ 26425-85, ГОСТ 26426-85, ГОСТ 26427-85, ГОСТ 26428-85. У статті наведено оцінку якості рекультивованих земель Олександрівського та Запорізького кар'єрів Орджонікідзевського гірничо-збагачувального комбінату (ступеня засолення, вмісту гумусу) на можливість їх господарського використання та придатності для існування грунтової біоти, а також надано рекомендації щодо їх подальшого раціонального використання. У ході досліджень виявлено, що за основними фізико-хімічними характеристиками досліджена територія рекультивації придатна для подальшого заселення та успішного існування грунтової біоти. Зроблено висновок, що в результаті технічного етапу рекультивації одержано штучний рекультивований грунт, який за характеристиками схожий із первинними зональними грунтами, розташованими на даних ділянках до проведення гірничих робіт; встановлено, що рекультивований грунт має меншу родючість та більшу засоленість горизонтів, однак здатний виконувати екологічні функції, слугуючи середовищем для існування грунтової біоти.

Ключові слова: якість рекультивованих грунтів; засоленість, видобувна промисловість; екосистемна оцінка; техногенез; грунтові безхребетні

\section{Вступ}

Невід'ємною умовою сталого економічного та соціального розвитку європейських держав $€$ охорона навколишнього середовища, раціональне використання природних ресурсів та забезпечення екологічної безпеки життедіяльності людини. У зв'язку 3 цим особливо актуальним $\epsilon$ вирішення екологічних проблем техногенно порушених територій Східної Свропи (Pecharova et al., 2011, Keesstra et al., 2016; Khaledian et al., 2012). Одним із потужних чинників, що призводить до деградації різних природних ландшафтів, $\epsilon$ діяльність видобувної промисловості. У результаті видобутку корисних копалин 3 використання вилучаються землі господарського призначення. На їх місці формуються техногенні ландшафти - відвали і кар'єри, а також деструктивні території, для яких характерні просідні явища, підйом i вихід на денну поверхню високомінералізованих грунтових вод, відведення на поверхню кислих шахтних вод, забруднення токсичними сполуками, зниження видового багатства і біологічного різноманіття угруповань таких ділянок (Kul'bachko et al., 2011, 2015, 2016; Jachimko 2012). Порушені території, утворені в процесі вуглевидобутку, частково відновлюють шляхом рекультивації. В Україні найбільш поширеною моделлю рекультивації сульфідних порід $є$ засипання їх суглинками, глиною, піском шаром 1-1,5 м із подальшим нанесенням на ці екрани $0,6-0,8$ м родючого грунту. На початковому етапі проводять коригування ландшафту і здійснюють нанесення родючого шару грунту. Основними агрохімічними характеристиками, які визначають продуктивність рекультивованих земель і ступінь їх придатності для існування біоти, є величина актуальної кислотності (pH) і ступінь засоленості.

Унаслідок інтенсивного промислового засвоєння території Дніпропетровщини набули змін морфології природних ландшафтів. Замість природних місць існування біоти виникли «промислові пустелі». Проблема спустелювання визнана світовою спільнотою як найсучасніша проблема всього людства. Особливо актуальна вона для посушливих регіонів України, зокрема для півдня Дніпропетровської області. У процесі виконання гірничо-технічного етапу рекультивації використовують субстрати 3 різною потенційною родючістю, які мають різні екологічні властивості, а отже $\mathrm{i}$ якість. Американське суспільство грунтознавців визначає термін «якість грунту» як здатність грунту функціонувати в межах екосистеми при забезпеченні біологічної продуктивності, підтримці якості довкілля і сприятливих умов існування тварин і рослин (Karaca, 2011). Таким чином, біологічна продуктивність рекультивованих грунтів є одним 3 декількох аспектів при визначенні якості грунту. Дослідники відзначають, що шахтна порода часто має високі значення щільності, низький коефіцієнт структурності, а також високу мінералізацію іiі водних витяжок, що в сукупності обумовлює надзвичайно низьку придатність таких субстратів для існування біоти (Kulbachko et al., 2016). Тому шахтну породу перекривають рекультиваційним шаром, який складається 3 нетоксичного матеріалу (незасолені лесоподібні суглинки, глини). Наступним етапом відновлювальних робіт $\epsilon$ нанесення родючого шару грунту. На території степової України для цього іноді використовують гумусовану масу чорнозему звичайного або безчорноземні варіанти насипок.

Заключним етапом відновлення порушених земель $\epsilon$ біологічний етап рекультивації. Його різновидами $\epsilon$ різні способи фіторекультивації з використанням трав'янистих, деревних і чагарникових насаджень (Lovinska et al., 2018), спрямовані на формування екологічно збалансованих ландшафтів. На цьому етапі рекультивації важливу роль у створенні механізмів стійкості екосистем відіграють чисельні живі організми, що оселюються в грунті (Maltseva, Baranova, 2014), зокрема грунтова мезофауна, представники ऑii сапротрофного комплексу - дощові черв'яки, енхітреїди, двопарноногі багатоніжки тощо (Pakhomov, Shulman 2017; Shulman et al., 2017; Brygadyrenko, 2016, 2018). Ці безхребетні в результаті трофо-метаболічної діяльності вносять значний екологічний внесок у перетворення грунтових властивостей. Їх називають «екосистемними інженерами», тобто організмами, здатними за допомогою своєї життєвої активності впливати на середовище проживання і грунтові угруповання біоти, а також викликати сукцесії екосистем. Доведено зростання ефективності відновлення рекультиземів при збагаченні їх копролітами дощових черв'яків, при одночасному поліпшенні якості насипних грунтів (Albrecht et al., 1998; Atiyeh et al., 2002; Blouin et al., 2013; Brevik, Sauer 2015). У сучасних умовах існує тенденція оцінювати ефективність рекультивації порушених земель за принципом досягнення 
максимального ефекту і мінімізації витрат з урахуванням взаємозв'язку всіх елементів екосистеми.

Серед біоти важливу роль у створенні механізмів стійкості агросистем відіграє грунтова мезофауна, зокрема представники іï сапротрофного комплексу - Lumbricidae, Diplopoda тощо. Ці тварини завдяки своїй трофометаболічній діяльності вносять значний екологічний внесок у перетворення грунтових властивостей, виступаючи як грунтозахисний біологічний фактор органічного землеробства. Можливість існування безхребетних у грунтах екосистем дуже тісно пов'язана 3 екологічними характеристиками (зволоженість, засоленість грунту, його механічний склад, наявність підстилки тощо. Грунтові тварини впливають на педогенез, родючість і структурованість грунту, регуляцію водного режиму та клімату, кругообіг речовин тощо, але при цьому, незважаючи на високу екологічну значущість, майже не враховуються екологічні умови існування безхребетних у грунті, особливо це стосується територій гірничих розробок.

Метою представленої роботи була оцінка якості рекультивованих земель Орджонікідзевського гірничозбагачувального комбінату на прикладі Олександрівського та Запорізького кар'єрів (Нікопольський район Дніпропетровської області) на можливість їх господарського використання і придатності для існування грунтової біоти, а також надання рекомендацій щодо подальшого раціонального господарського використання. Предметом представлених досліджень $є$ оцінка якості проведення рекультивації грунтів 3 метою виявлення умов для існування представників зооценотичного блоку. Об'єктом дослідження є фізико-хімічні властивості рекультивованих грунтів ОГЗК Олександрівського та Запорізького кар'єрів (потужність насипного гумусованого шару, вміст гумусу в насипному шарі, засолення насипного родючого шару і підстилаючої породи (ступінь), склад і властивості підстилаючих порід).

\section{Матеріали та методи досліджень}

Обстежена територія рекультивації Запорізького кар'єру розташована на території Покровської сільської ради, вона займає площу 8,9 га та призначається для використання в орних угіддях. Територія належить до Апостолівського природно-сільськогосподарського району, провінція Степова посушлива. Обстежена площа рекультивації представлена однією ділянкою. Для проведення досліджень у межах даної ділянки було закладено два грунтових розрізи. Нанесений шар гумусованої чорноземної маси являє собою суміш гумусового та перехідних горизонтів чорнозему звичайного. Потужність чорноземного шару дорівнює 5660 см. У середньому глибина насипного родючого шару становить 58,0 см. Чорноземний шар частини території не несе ознак засолення. Нижче плужної підошви чорнозем ущільнений. По всьому профілю наявні карбонати кальцію у вигляді білуватих вкраплень. Породи, що підстилають чорноземний шар, представлені сумішшю лесових суглинків та червоних глин.

Обстежена площа Олександрівського кар'єру становить приблизно 10,0 га. Як картографічна основа при проведенні польового обстеження використовувались плани гірничих робіт масштабу 1:5 000. Кожна ділянка розбивалась на квадрати, в кутах яких закладались шурфи i свердловини. Кількість закладених шурфів та свердловин 2 , кількість відібраних зразків - 30 (10 у трикратній повторності). Агрохімічні аналізи зразків грунтів і порід виконані в лабораторії ДП «Дніпропетровський науководослідний та проектний інститут землеустрою». Аналіз водної витяжки проводили згідно 3 ГОСТ 26425-85 «Грунти. Методи визначення йону хлориду в водній витяжці», ГОСТ 26426-85 «Грунти. Методи визначення йону сульфату в водній витяжці», ГОСТ 26427-85 «Грунти. Метод визначення натрію та калію у водній витяжці», ГОСТ 26428-85 «Грунти. Методи визначення кальцію та магнію в водній витяжці».

Коротка характеристика гірничо-технічного етапу рекультивації. Гірничо-технічна рекультивація обстежених ділянок була виконана ПАТ «ОГЗК» і включала в себе такі етапи:

1. Зняття родючого шару грунту (чорнозему) валовим способом 3 наступним складуванням у бурти.

2. Переформування i розрівнювання відвалів розкривних порід надрудної товщі, що складуються у відпрацьованому просторі кар'єру валовим способом.

3. Витримування до 3 років вирівняної поверхні відвалів $з$ метою просідання порід.

4. Ремонт поверхні після просадок.

5. Нанесення родючого шару грунту.

6. Оранка рекультивованих земель.

Клімат та умови зволоження трунтів. Район Нікопольського марганцеворудного басейну за вологозабезпеченістю відноситься до посушливого. Гідротермічний коефіцієнт $0,8-0,9$. Середньорічні опади становлять 401 мм. Середньодекадна кількість опадів - 720 мм, при цьому максимум їх спостерігається у червнілипні (17-20 мм). Середньорічна температура повітря $+8,8{ }^{\circ} \mathrm{C}$. Тривалість активних температур більше $+5{ }^{\circ} \mathrm{C}$ становить 214 днів, їх сума - $3487^{\circ} \mathrm{C}$. Тривалість температур більше $+10{ }^{\circ} \mathrm{C}-178$ днів, сума цих температур $3216{ }^{\circ} \mathrm{C}$. Для температурного режиму характерні значні перепади, що приводить до інтенсивного вивітрювання гірничих порід рекультивованих земель 3 вивільненням елементів мінерального живлення рослин. Несприятливі кліматичні показники - тривалі бездощові періоди 3 відносною вологістю повітря до 30 \% та сильні посушливі вітри. Зволоження рекультивованих грунтів відбувається тільки за рахунок атмосферних опадів. Обстежена площа рекультивації Олександрівського кар'єру розташована на території Покровської сільської ради, займає площу 10,0 га i призначається для використання в орних угіддях. Територія належить до Апостолівського природносільськогосподарського району, провінція Степова посушлива Правобережна. Нахил поверхні обстеженої ділянки не перевищує $1^{\circ}$. Мікрознижень та інших деформацій поверхні від просадок грунту не виявлено. Обстежена площа рекультивації є однією ділянкою.

Характеристика оціночних одиниць. Бонітування грунтів - це порівняльна оцінка їх родючості, яка визначає ступінь придатності грунтів для вирощування сільськогосподарських культур. При проведенні оцінки непорушених земель за оціночну одиницю прийнято агровиробничу групу грунтів єдиного для країни номенклатурного списку. Стосовно рекультивованих грунтів виділити подібні оціночні групи і скласти єдиний список не $\epsilon$ можливим, оскільки параметри фактичної рекультивації не завжди відповідають проектним параметрам. Згідно з проектними даними у рекультивованих земель має бути насипний гумусований шар потужністю $50 \mathrm{~cm}$, який підстилається незасоленими лесоподібними суглинками на глибину 150 см. Збір даних щодо властивостей рекультивованих земель здійснюється по ділянках виконаної рекультивації. Дані одержували 3 матеріалів грунтово-агрохімічного дослідження. Механічний склад рекультивованих грунтів Олександрівського кар'єру характеризували як склад шару насипного чорнозему плюс склад підстилаючих порід. Дослідження грунтових умов проводилося шляхом закладання серії грунтових розрізів. Збір і обробку даних проведено за такими показниками: 1) потужність насипного гумусованого шару, см; 2) вміст гумусу в насипному шарі, \%; 3) засолення насипного родючого шару і підстилаючих порід (ступінь); 4) склад і властивості підстилаючих порід. 
Вміст гумусу визначали за ДСТУ 4289:2004 «Якість грунту. Метод визначення органічної речовини» Аналіз водної витяжки проводили згідно з ГОСТ 26425-85 «Грунти. Методи визначення йону хлориду у водній витяжці», ГОСТ 26426-85 «Грунти. Методи визначення йону сульфату у водній витяжці», ГОСТ 26427-85 «Грунти. Метод визначення натрію та калію у водній витяжці», ГОСТ 26428-85 «Грунти. Методи визначення кальцію та магнію у водній витяжці». Гранулометричний склад насипного шару грунту визначали згідно з ГОСТ 12536-79 «Грунти. Методи лабораторного визначення зернового (гранулометричного) складу».

3 метою бонітування складають шкалу балів бонітету, причому за 100 балів приймають найкращий (найродючіший) грунт району бонітування. Для врахування грунтових процесів, які значуще впливають на врожайність, але недостатньо виявляються 3 використанням кількісних показників, застосовують коригуючі коефіцієнти, специфічні для конкретних територій. Для розрахунку балів бонітування рекультивованих земель на перших етапах використовують три перших показники, інші показники родючості застосовуються як поправкові коефіцієнти. Розраховані бали бонітету порівнюють 3 балами еталонного зонального грунту і роблять висновки щодо цінності даного грунту 3 позиції вирошування сільськогосподарських культур, а також використовують для проведення економічних розрахунків грошової оцінки земель.

За даними грунтового обстеження на місці ділянок рекультивації Олександрівського та Запорізького кар'єрів раніше були сформовані чорноземи південні середньосуглинкові та чорноземи звичайні малогумусові неглибокі важкосуглинкові. Як еталон для бонітування рекультивованих земель, що використовуються в орних угіддях, приймається в даній зоні чорнозем звичайний малогумусовий неглибокий важкосуглинковий. Цей грунт характеризується такими основними показниками: глибина гумусових горизонтів $(\mathrm{H}+\mathrm{Hp})-54$ см; вміст гумусу в орному шарі $-3,5 \%$; вміст фізичної глини в орному шарі $54,8 \%$. Бал бонітету $-84,3$ урахуванням екологічного коефіцієнту - 41. Вищенаведені дані необхідні для оцінки рекультивованих земель. Представлені грунти добре забезпечені нітрогеном та фосфором, високо - калієм, вони мають нейтральну реакцію грунтового розчину. Карбонати знаходяться на глибині 35-45 см, засолення відсутнє. Грунтоутворюючими породами $\epsilon$ леси та лесоподібні суглинки. Таким чином, чорноземи звичайні малогумусові неглибокі важкосуглинкові належать до категорії найбільш цінних земель універсального використання. Оцінка ефективності рекультивації земель $є$ складовою частиною грунтово-агрохімічного обстеження і включає бонітування рекультивованих грунтів.

\section{Результати та їх обговорення}

Характеристика рекультивованих трунтів Олександрівського кар'єру. Підстилаючі породи. Породи, що підстилають чорноземний шар, не відрізняються строкатістю і представлені техногенною сумішшю лесових суглинків i червоно-бурих глин. Підстилаючі породи Олександрівського кар'єру (за даними хімічних аналізів) містять водорозчинні солі вище порогу токсичності на глибині 30-100 см. Підстилаючі породи є слабо- та середньозасоленими за сульфатним типом.

Якість родючого шару трунту. При селективному знятті гумусового шару зонального грунту, який у подальшому використовують для рекультивації, відбувається його змішування 3 безгумусовим лесоподібним суглинком, в результаті чого родючий шар грунту збіднюється на поживні для рослин речовини, особливо на доступний нітроген, стає більш карбонатним $\mathrm{i}$ містить 1,6-2,0 \% гумусу, тобто у 1,5-2 рази менше, ніж в орному шарі первинного грунту. Нанесений чорноземний шар являє собою суміш гумусового i перехідних горизонтів чорнозему південного. Він має сіруватокоричневе, місцями плямисте забарвлення, обумовлене вкрапленнями палевого лесоподібного суглинку. Вміст гумусу в шарі 0-10 см коливається від 2,1 до 2,3 \% і в середньому становить $2,2 \%$. Потужність чорноземного шару - від 56 см до 67 см. У середньому глибина насипного родючого шару становить $62 \mathrm{~cm}$. Засолення водорозчинними солями вище порогу токсичності в орному шарі досліджених грунтів не виявлено (табл. 1). Нижче плужної підошви грунт ущільнений. По всьому його профілю наявні карбонати кальцію.

Визначення впливу підстилаючих порід на продуктивність рекультивованих земель. Багаторічними дослідженнями Дніпропетровського сільськогосподарського інституту на рекультивованих землях Орджонікідзевського ГЗК виявлено негативний вплив засолених порід на продуктивність рекультивованих земель. В умовах Олександрівського кар'єру коефіцієнт впливу дорівнює 0,76.

Засолення рекультивованих трунтів. Аналіз водних витяжок рекультивованих грунтів Олександрівського кар'єру виявив наявність водорозчинних солей вище порогу токсичності в підстилаючих породах. Рекультивовані грунти за типом засолення $\epsilon$ слабозасоленими солончакуватими на площі 6,1 га (засолені на глибині 30-80 см) та середньозасоленими солончакуватими на площі 3,9 га. Тип засолення сульфатний (табл. 1).

Оиінка рекультивованих трунтів. Бонітування рекультивованих земель на агроекологічній основі здійснюють за грунтово-екологічними індексами. Такий підхід надає можливість урахувати практично весь комплекс абіотичних та біотичних чинників у системі техногенний едафотоп - рослина. Згідно 3 роботами M. О. Бекаревича продуктивність рекультивованих едафотопів визначається такими чинниками, як вміст гумусу та поживних речовин, потужність насипного гумусованого шару, фізичні властивості підстилаючих порід у метровому шарі, вміст водорозчинних солей та карбонатів тощо. Дослідженнями встановлено, що продуктивність рекультивованих грунтів у процесі їх експлуатації не досягає рівня продуктивності непорушених грунтів.

Характеристика рекультивованих трунтів Запорізького кар’єру. Підстилаючі породи. До порід, що підстилають родючий шар грунту на обстеженій території, відносяться лесові плейстоценові відклади (до 3 ярусів), червоно-бурі пліоценові глини та техногенна суміш вищеназваних порід. У складі підстилаючих порід досліджених територій переважає техногенна суміш лесових суглинків та червоних глин. Лесові породи слабота середньозасолені. Тип засолення - сульфатний та хлоридно-сульфатний.

Якість родючого шару трунту. У результаті проведення гірничих робіт родючий шар рекультивованого грунту збіднюється на поживні для рослин речовини, стає більш карбонатним і містить у 1,5-2,0 разу менше гумусу, ніж орний шар первинного грунту (Mueller et al., 2016). Потужність гумусованого шару в середньому становить $58 \mathrm{~cm}$ порівняно із $54 \mathrm{~cm}$ для зональних грунтів. Вміст гумусу в насипному шарі в середньому становить 2,2\% порівняно зі значенням 3,5 cм для зональних грунтів. Нижче плужної підошви грунт ущільнений.

Визначення впливу підстилаючих порід на продуктивність рекультивованих земель. Багаторічними дослідженнями Дніпропетровського сільськогосподарського інституту на рекультивованих землях Орджонікідзевського ГЗК в умовах Запорізького кар'єру не виявлено негативного впливу засолених порід на продуктивність рекультивованих земель. 
Таблиця 1

Результати аналізу водорозчинних сполук рекультивованих грунтів Олександрівського кар’єру ПАТ «ОГЗК»

\begin{tabular}{|c|c|c|c|c|c|c|c|c|c|c|c|}
\hline \multirow{2}{*}{$\begin{array}{l}\text { № } \\
\text { розрізу }\end{array}$} & \multirow{2}{*}{$\begin{array}{c}\text { Індекс } \\
\text { горизонтів }\end{array}$} & \multirow{2}{*}{$\begin{array}{c}\text { Глибина } \\
\text { відбору } \\
\text { зразка, } \\
\text { см }\end{array}$} & \multicolumn{9}{|c|}{$\begin{array}{c}\text { Водна витяжка, } \\
\text { \%мг-екв на } 100 \text { г грунту }\end{array}$} \\
\hline & & & $\begin{array}{c}\text { сухий } \\
\text { залишок }\end{array}$ & $\mathrm{CO}_{3}{ }^{2-}$ & $\mathrm{HCO}_{3}^{-}$ & $\mathrm{Cl}^{-}$ & $\mathrm{SO}_{4}{ }^{2-}$ & $\mathrm{Ca}^{2+}$ & $\mathrm{Mg}^{2+}$ & $\mathrm{Na}^{+}$ & $\begin{array}{c}\mathrm{pH} \\
\text { водний }\end{array}$ \\
\hline \multirow{5}{*}{1} & $\mathrm{H}+\mathrm{Hp}+\mathrm{Ph}$ & $0-10$ & $0,106 \pm 0,07$ & - & $0,83 \pm 0,03$ & 0,29 & 0,40 & 0,73 & 0,73 & 0,06 & 6,78 \\
\hline & $\mathrm{H}+\mathrm{Hp}+\mathrm{Ph}$ & $20-30$ & $0,078 \pm 0,01$ & - & $0,56 \pm 0,02$ & 0,15 & 0,54 & 0,73 & 0 & 0,52 & 6,56 \\
\hline & $\mathrm{H}+\mathrm{Hp}+\mathrm{Ph}$ & $40-50$ & $0,106 \pm 0,03$ & - & $0,74 \pm 0,03$ & 0,29 & 0,50 & 0,62 & 0,82 & 0,09 & 7,02 \\
\hline & $\mathrm{H}+\mathrm{Hp}+\mathrm{Ph}$ & $58-67$ & $0,404 \pm 0,03$ & - & $0,56 \pm 0,02$ & 0,73 & 4,75 & 2,50 & 2,08 & 1,46 & 7,16 \\
\hline & $\mathrm{Pk}$ & $90-100$ & $0,387 \pm 0,02$ & - & $0,56 \pm 0,02$ & 0,80 & 4,31 & 2,06 & 3,09 & 0,52 & 7,98 \\
\hline \multirow{5}{*}{2} & $\mathrm{H}+\mathrm{Hp}+\mathrm{Ph}$ & $0-10$ & $0,087 \pm 0,04$ & - & 0,62 & 0,11 & 0,40 & 0,62 & 0,21 & 0,30 & 6,82 \\
\hline & $\mathrm{H}+\mathrm{Hp}+\mathrm{Ph}$ & $20-30$ & $0,104 \pm 0,05$ & - & 0,74 & 0,32 & 0,50 & 0,73 & 0,83 & 0 & 7,12 \\
\hline & $\mathrm{H}+\mathrm{Hp}+\mathrm{Ph}$ & $40-50$ & $0,281 \pm 0,07$ & - & 0,60 & 0,55 & 3,21 & 1,98 & 1,14 & 1,24 & 7,54 \\
\hline & $\mathrm{H}+\mathrm{Hp}+\mathrm{Ph}$ & $48-56$ & $0,526 \pm 0,05$ & - & 0,56 & 0,94 & 6,20 & 2,29 & 2,18 & 3,23 & 7,56 \\
\hline & $\mathrm{Pk}$ & $90-100$ & $0,620 \pm 0,04$ & - & 0,50 & 0,89 & 7,77 & 2,60 & 2,60 & 3,96 & 8,12 \\
\hline
\end{tabular}

У результаті проведеної рекультивації було одержано штучні грунти, що характеризуються такими основними показниками: глибина гумусових горизонтів (Н+Hр) 62 см; вміст гумусу в орному шарі $-2,2 \%$; вміст фізичної глини в орному шарі - 45,3 \%. Бал бонітету - 62, 3 урахуванням екологічного коефіцієнту -30 , у той час як бал бонітету природних грунтів становить 41 (табл. 2).

\section{Таблиця 2}

Результати розрахунків балів бонітету за властивостями рекультивованих грунтів Олександрівського кар'єру ПАТ «ОГЗК»

\begin{tabular}{|c|c|c|c|c|c|c|c|c|c|c|c|c|c|c|}
\hline \multirow[b]{3}{*}{ Назва грунтів } & \multicolumn{9}{|c|}{ Властивості грунтів та їх оцінка в балах } & \multirow{3}{*}{ 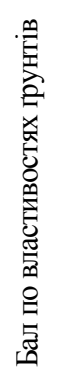 } & \multirow{2}{*}{\multicolumn{2}{|c|}{$\begin{array}{c}\text { Поправкові } \\
\text { коефіцієнти на: }\end{array}$}} & \multirow{2}{*}{\multicolumn{2}{|c|}{ Остаточний бал }} \\
\hline & \multicolumn{3}{|c|}{$\begin{array}{c}\text { глибина гумусових } \\
\text { горизонтів }\end{array}$} & \multicolumn{3}{|c|}{$\begin{array}{c}\text { вміст гумусу } \\
\text { в орному шарі }\end{array}$} & \multicolumn{3}{|c|}{ вміст фізичної глини } & & & & & \\
\hline & 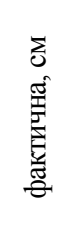 & క్ర్ర & 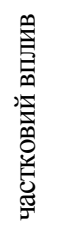 & 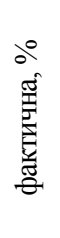 & డ్ర్రి & 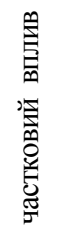 & 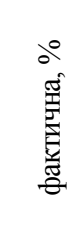 & శ్ర్ర్ & 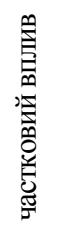 & & 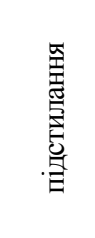 & 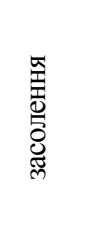 & 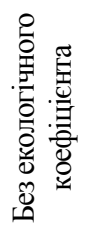 & 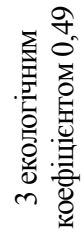 \\
\hline $\begin{array}{l}\text { Чорнозем звичайний } \\
\text { малогумусовий } \\
\text { неглибокий } \\
\text { важкосуглинковий }\end{array}$ & 54 & - & - & 3,5 & - & - & 54,8 & - & - & - & - & - & 84 & 41 \\
\hline $\begin{array}{l}\text { Рекультивовані грунти } \\
\text { (у середньому } \\
\text { по ділянці) }\end{array}$ & 62 & 114 & 95 & 2,2 & 63 & 47 & 45,3 & 94 & 53 & 91 & 0,90 & 0,76 & 62 & 30 \\
\hline
\end{tabular}

Засолення рекультивованих трунтів. Аналіз водних витяжок показав, що у складі катіонів домінуюча роль належить кальцію та магнію. Катіони натрію наявні в низькій концентрації та в орному шарі сягають максимального значення 1,07 мг-екв/100 г грунту на глибині 23-30 см рекультизему. Але це значення одиничне, і в більшості випадків концентрація катіонів натрію в орному шарі не перевищує 0,32 мг-екв/100 г грунту. У складі аніонів переважають сульфати, а хлориди та карбонати займають підпорядковане положення (табл. 3).

На глибині 90-100 см обох грунтових профілів спостерігається деяке підвищення концентрації натрію до 0,25 і 0,79 мг-екв/100 г грунту, але на цій глибині токсична дія натрію не виявляється. Згідно $з$ показниками сухого залишку, вираженими у відсотках, засолення в орному шарі рекультизему не спостерігається, оскільки ці показники не перевищують 0,30 \% на глибині 0-10 см обох грунтових розрізів. У підстилаючій породі розрізу 1 на глибині 90-100 см показник сухого залишку сягає $0,30 \%$, що характеризує породу на цій глибині як слабозасолену, однак це в подалышому не вплине на генезу рекультизему, оскільки в умовах вододілу майже відсутній вплив підгрунтових вод на грунтовий профіль. Результати аналізу водної витяжки грунтового розрізу 2 показали відсутність засолення по всьому профілю рекультизему.

Також у ході аналізу водних витяжок рекультивованих грунтів не спостерігалась наявність водорозчинних солей вище порогу токсичності у насипному чорноземному шарі на всій території ділянки. Для визначення балу бонітету рекультивованих грунтів Запорізького кар'єру були використані наведені показники їх властивостей (у середньому по ділянці). 
Таблиця 3

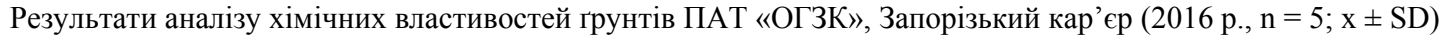

\begin{tabular}{|c|c|c|c|c|c|c|c|c|c|}
\hline \multirow[b]{3}{*}{$\begin{array}{c}\text { № } \\
\text { poзрiзу }\end{array}$} & \multirow[b]{3}{*}{$\begin{array}{c}\text { Глибина } \\
\text { відбору } \\
\text { зразка, см }\end{array}$} & \multirow[b]{3}{*}{$\begin{array}{c}\text { Індекс } \\
\text { горизонту }\end{array}$} & \multicolumn{7}{|c|}{ Водна витяжка } \\
\hline & & & \multirow[b]{2}{*}{$\begin{array}{c}\text { сухий } \\
\text { залишок, \% }\end{array}$} & \multicolumn{6}{|c|}{ аніонно-катіонний склад, мг-екв/100 г грунту } \\
\hline & & & & $\mathrm{HCO}^{3-}$ & $\mathrm{Cl}^{-}$ & $\mathrm{SO}_{4}{ }^{2-}$ & $\mathrm{Ca}^{2+}$ & $\mathrm{Mg}^{2+}$ & $\mathrm{Na}^{+}$ \\
\hline \multirow{5}{*}{1} & $0-10$ & $\mathrm{H}+\mathrm{Hp}+\mathrm{Ph}$ & $0,076 \pm 0,012$ & $0,06 \pm 0,011$ & $0,73 \pm 0,030$ & $0,44 \pm 0,022$ & $0,73 \pm 0,051$ & $0,42 \pm 0,024$ & $0,08 \pm 0,011$ \\
\hline & $20-30$ & $\mathrm{H}+\mathrm{Hp}+\mathrm{Ph}$ & $0,110 \pm 0,011$ & $0,83 \pm 0,012$ & $0,17 \pm 0,011$ & $0,62 \pm 0,023$ & $0,83 \pm 0,032$ & $0,72 \pm 0,031$ & $0,07 \pm 0,010$ \\
\hline & $40-50$ & $\mathrm{H}+\mathrm{Hp}+\mathrm{Ph}$ & $0,338 \pm 0,015$ & $0,58 \pm 0,040$ & $0,58 \pm 0,024$ & $4,16 \pm 0,162$ & $2,91 \pm 0,064$ & $2,29 \pm 0,051$ & $0,12 \pm 0,012$ \\
\hline & $56-62$ & $\mathrm{H}+\mathrm{Hp}+\mathrm{Ph}$ & $0,196 \pm 0,025$ & $0,58 \pm 0,010$ & $0,62 \pm 0,032$ & $1,64 \pm 0,050$ & $1,14 \pm 0,020$ & $1,66 \pm 0,036$ & $0,04 \pm 0,010$ \\
\hline & $90-100$ & $\mathrm{Pk}$ & $0,300 \pm 0,012$ & $0,58 \pm 0,031$ & $0,60 \pm 0,030$ & $3,23 \pm 0,142$ & $1,98 \pm 0,015$ & $2,18 \pm 0,042$ & $0,25 \pm 0,010$ \\
\hline \multirow{5}{*}{2} & $0-10$ & $\mathrm{H}+\mathrm{Hp}+\mathrm{Ph}$ & $0,208 \pm 0,010$ & $0,69 \pm 0,031$ & $0,69 \pm 0,021$ & $1,75 \pm 0,036$ & $1,56 \pm 0,022$ & $1,25 \pm 0,020$ & $0,32 \pm 0,010$ \\
\hline & $20-30$ & $\mathrm{H}+\mathrm{Hp}+\mathrm{Ph}$ & $0,275 \pm 0,032$ & $0,71 \pm 0,020$ & $0,73 \pm 0,031$ & $2,75 \pm 0,052$ & $1,98 \pm 0,026$ & $1,14 \pm 0,010$ & $1,07 \pm 0,022$ \\
\hline & $40-50$ & $\mathrm{H}+\mathrm{Hp}+\mathrm{Ph}$ & $0,218 \pm 0,003$ & $0,44 \pm 0,024$ & $0,73 \pm 0,02$ & $2,10 \pm 0,040$ & $1,98 \pm 0,020$ & $1,25 \pm 0,011$ & $0,04 \pm 0,010$ \\
\hline & $56-63$ & $\mathrm{H}+\mathrm{Hp}+\mathrm{Ph}$ & $0,178 \pm 0,001$ & $0,48 \pm 0,031$ & $0,69 \pm 0,011$ & $1,71 \pm 0,025$ & $1,56 \pm 0,021$ & $1,25 \pm 0,024$ & $0,07 \pm 0,010$ \\
\hline & $90-100$ & $\mathrm{Pk}$ & $0,187 \pm 0,002$ & $0,58 \pm 0,041$ & $0,73 \pm 0,030$ & $1,46 \pm 0,010$ & $0,94 \pm 0,011$ & $1,04 \pm 0,010$ & $0,79 \pm 0,031$ \\
\hline
\end{tabular}

Проведені дослідження свідчать, що одержані в результаті рекультивації штучні грунти за балом бонітету схожі із зональними чорноземами звичайними малогумусовими неглибокими важкосуглинковими. Остаточний бал бонітету рекультивованих грунтів становить 43, у той час як бал природних грунтів дорівнює 41 (табл. 4). Цей факт свідчить про те, що рекультиваційні роботи на дослідженій території гірничих розробок ПАТ «ОГЗК» (на прикладі Запорізького кар'єру) були проведені на належному рівні.

\section{Таблиця 4}

Результати розрахунків балів бонітету за властивостями рекультивованих грунтів Запорізького кар’єру ПАТ «ОГЗК»

\begin{tabular}{|c|c|c|c|c|c|c|c|c|c|c|c|c|c|c|}
\hline \multirow[b]{3}{*}{ Назва грунту } & \multicolumn{9}{|c|}{ Властивості грунтів та їх оцінка в балах } & \multirow{3}{*}{ 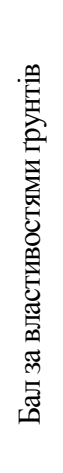 } & \multirow{2}{*}{\multicolumn{2}{|c|}{$\begin{array}{c}\text { Поправкові } \\
\text { коефіцієнти на: }\end{array}$}} & \multirow{2}{*}{\multicolumn{2}{|c|}{ Остаточний бал }} \\
\hline & \multicolumn{3}{|c|}{$\begin{array}{c}\text { Глибина гумусових } \\
\text { горизонтів }\end{array}$} & \multicolumn{3}{|c|}{$\begin{array}{l}\text { Вміст гумусу в } \\
\text { орному шарі }\end{array}$} & \multicolumn{3}{|c|}{$\begin{array}{c}\text { Вміст фізичної } \\
\text { глини }\end{array}$} & & & & & \\
\hline & 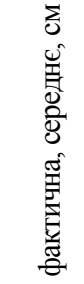 & డ్ర్ర & 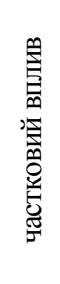 & 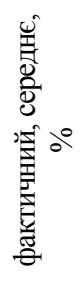 & డ్ర్ & 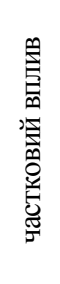 & 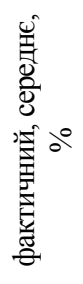 & డ్ర్ర & 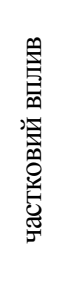 & & 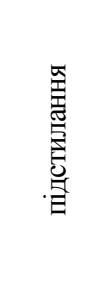 & 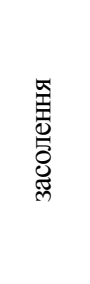 & 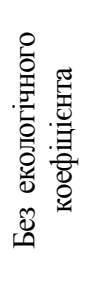 & 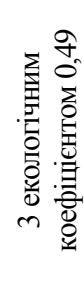 \\
\hline $\begin{array}{c}\text { Чорнозем } \\
\text { звичайний } \\
\text { малогумусовий } \\
\text { неглибокий } \\
\text { важкосуглинковий }\end{array}$ & 54 & H3 & H3 & 3,5 & H3 & H3 & 54,8 & H3 & H3 & H3 & H3 & H3 & 84 & 41 \\
\hline $\begin{array}{c}\text { Рекультивовані } \\
\text { грунти } \\
\text { (у середньому } \\
\text { по ділянці) }\end{array}$ & 58 & 107 & 89 & 2,2 & 63 & 47 & 52,9 & 100 & 55 & 90 & 0,97 & 1,00 & 87 & 43 \\
\hline
\end{tabular}

Примітка. Н3 - не застосовується.

У результаті проведення гірничих робіт родючий шар рекультивованого грунту збіднюється на поживні для рослин речовини, стає більш карбонатним і містить у 1,52,0 разу менше гумусу, ніж орний шар первинного грунту. Потужність гумусованого шару в середньому становить 58 см порівняно із 54 см для зональних грунтів. Вміст гумусу в насипному шарі в середньому становить $2,2 \%$ порівняно зі значенням 3,5 см для зональних грунтів. Аналіз водних витяжок не виявив наявність водорозчинних солей вище порогу токсичності у підстилаючих породах (табл. 3). По всьому профілю грунту містяться карбонати кальцію.
Для рекультивованих грунтів характерна менша кількість гумусу, але слід очікувати, що в процесі проведення біологічного етапу рекультивації вони поступово збагатяться на органічну речовину, у результаті чого кормова база для грунтових тварин у подальшому покращиться. Також відбудеться поліпшення окремих екологічних характеристик грунту, зокрема збільшиться його шпаруватість, що є дуже важливим для оптимізації властивостей грунту важкого механічного складу. Ці самі положення стосуються майбутнього сільськогосподарського використання дослідженої ділянки. Можна прогнозувати, 
що після проведення біологічного етапу рекультивації, тобто після засівання рекультивованих грунтів екологічно стійкими багаторічними травами (люцерна жовта (Medicago falcata L.), стоколос безостий (Bromus inermis L.), пирій повзучий (Elytrigia repens L.); стоколос безостий (Bromus inermis L.), люцерна синьогібридна (Medicago varia Mart.)), відбудеться подальше поліпшення екологічних властивостей грунту.

Проведені дослідження показали, що рекультиваційні роботи на території гірничих розробок ВАТ «ОГЗК» (на прикладі Олександрівського та Запорізького кар'єрів) проведені на належному рівні. У результаті проведення гірничих робіт родючий шар рекультивованого грунту збіднюється на поживні для рослин речовини, стає більш карбонатним і містить у 1,5-2 рази менше гумусу, ніж орний шар первинного грунту. Потужність гумусованого шару в середньому становить 58-62 см. Вміст гумусу в насипному шарі в середньому складає $2,2 \%$. Механічний склад орного шару грунту - середньосуглинковий. Нижче плужної підошви грунт ущільнений. Засолення водорозчинними солями вище порогу токсичності в орному шарі досліджених грунтів не виявлено. Аналіз водних витяжок виявив наявність водорозчинних солей вище порогу токсичності у підстилаючих породах. Рекультивовані грунти Олександрівського кар'єру за типом засолення $є$ слабозасоленими солончакуватими на площі 6,1 га та середньозасоленими солончакуватими на площі 3,9 га. Тип засолення - сульфатний. По всьому профілю грунту наявні карбонати кальцію. Рекультивовані грунти Запорізького кар'єру не мають ознак засолення.

Рекомендації щодо поліпшення рекультивованих земель. Перш ніж розпочати використання рекультивованих земель в орних угіддях, необхідно провести ремонт рекультивованих земель (при необхідності) та біологічну рекультивацію (обов'язково). На біологічному етапі поліпшуються агрофізичні властивості (структура, шпаруватість, повітряний режим, водопроникність), агрохімічні (збагачення гумусом i поживними речовинами), хімічні (винесення із грунту легкорозчинних солей). Це досягається завдяки вирощуванню протягом 3-5 років солевитривалих багаторічних трав. Для цього рекомендуємо використання таких травосумішей: люцерна жовта (Medicago falcata L.) + стоколос безостий (Bromus inermis L.) + пирій повзучий (Elytrigia repens L.); стоколос безостий (Bromus inermis L.) + люцерна синьогібридна (Medicago varia Mart.). Технологічна низка робіт з біологічної рекультивації повинна розроблятися окремим робочим проектом.

\section{Висновки}

У результаті технічного етапу рекультивації одержано штучний рекультивований грунт, який за характеристиками $є$ схожим із первинними зональними грунтами, розташованими на даній ділянці до проведення гірничих робіт, i, хоча має дещо меншу родючість та більшу засоленість нижніх горизонтів, може використовуватись для господарських цілей. Поправкові коефіцієнти на підстилання та засолення не змінюють значно результати оцінювання грунту, що свідчить про близькість його основних фізичних та хімічних характеристик до зонального природного чорнозему. Результати дослідів свідчать про те, що в штучно створеному грунті території рекультивації Олександрівського та Запорізького кар'єрів ВАТ «ОГЗК» у майбутньому складуться екологічні умови, сприятливі для існування грунтових безхребетних. Можна прогнозувати, що після проведення біологічного етапу рекультивації, який полягає у засіванні рекультивованих грунтів екологічно стійкими багаторічними травами, відбудеться подальше поліпшення екологічних властивостей грунту та складуться оптимальні умови для існування угруповань безхребетних тварин, притаманних природним зональним грунтам, що приведе до їх подальшої натуралізації, підвищення екологічної стійкості та продуктивності.

\section{Висновки}

Представлена робота проводилась у НДІ біології Дніпровського національного університету ім. О. Гончара. Матеріали $\epsilon$ частиною досліджень у рамках держбюджетних тем Міністерства освіти і науки України: д/б № 1-325-17 «Екологічні основи зоопертинентного впливу тварин на процеси оптимізації природних i порушених екосистем в умовах сучасного природокористування», д/б № 1-290-15 «Зоогенні механізми екосистемних сервісів та розробка екологічних принципів їх збереження і відновлення», а також договірної роботи 3 ДП «Дніпропетровський науководослідний та проектний інститут землеустрою». Автори виражають подяку інженерам Назімову С. С., Неклесі А. О., провідному спеціалісту Міщенко Л. В. за допомогу та співробітництво у науково-дослідній роботі.

\section{References}

Albrecht, A., Angers, D. A., Beare, M. H., Blanchart, E. (1998). Soil aggregation, soil organic matter and soil biota interactions: implications for soil fertility recapitalization in the tropics. Cahiers Agricultures, 7(5), 357-363.

Atiyeh, R. M., Lee, C., Edwards, A., Arancon, N. Q., Metzger, J. D. (2002). The influence of humic acids derived from earthworm-processed organic wastes on plant growth. Bioresource Technology, 84(1), 7-14.

Blouin, M., Hodson, M. E., Delgado, E. A. (2013). A review of earthworm impact on soil function and ecosystem services. Journal of European Soil Science, 64(1), 161-182.

Brevik E. C., Sauer T. J. (2015). The past, present, and future of soils and human health studies. Soil, 1(1), 35-46.

Brygadyrenko V. V. (2016). Influence of litter thickness on the structure of litter macrofauna of deciduous forests of Ukraine's steppe zone. Visnik Dnipropetovsk University. Series Biology, Ecology, 24(1), 240-248.

Jachimko B. (2012). The influence of lignite mining on water quality. in: Voudouris K, Voutsa D. (eds) Water Quality Monitoring and Assessment. InTech, Croatia, 373-390.

Karaca A. (2011). Biology of Earthworms, Soil Biology 24, Springer-Verlag Berlin Heidelberg.

Keesstra, S. D., Bouma, J., Wallinga, J., Tittonell, P., Smith, P., Cerdà, A., Montanarella, L., Quinton, J. N., Pachepsky, Y., van der Putten, W. H., Bardgett, R. D., Moolenaar, S., Mol, G., Jansen, B., Fresco L. O. (2016). The significance of soils and soil science towards realization of the United Nations Sustainable Development Goals. Soil, 2(1), 111-128.

Khaledian, Y., Kiani, F., Ebrahimi, S. (2012). The effect of land use change on soil and water quality in Northern Iran. Journal of Mountain Science, 9(6), 798-816.

Khaledian, Y., Kiani, F., Ebrahimi, S., Brevik, E. C., Aitkenhead-Peterson, J. (2017). Assessment and monitoring of soil degradation during land use change using multivariate analysis. Land Degradation and Development, 28(1), 128-141.

Kul'bachko, Y., Loza, I., Pakhomov, O., Didur, O. (2011). The zoological remediation of technogen faulted soil in the industrial region of the Ukraine Steppe zone. Sustainable Agricultural Development, Springer Science+Business Media, New York, 115-123.

Kulbachko, Y. L., Didur, O. A., Loza, I. M., Kryuchkova, A. I. (2016). Effects of saprophages (Earthworms, Lumbricidae, and Millipedes, Diplopoda) on ecosystem services implementation: optimization of some ecological functions in remediated soil. In: Issues of the ecosystem services provided by animals under anthropogenic pressure within 
Ukrainian steppe. East West Association for Advanced Studies and Higher Education GmbH, 62-87.

Kul'bachko. Y. L., Didur, O. O., Loza, I. M., Pakhomov, O. E., Bezrodnova, O. V. (2015). Environmental aspects of the effect of earthworm (Lumbricidae, Oligochaeta) trophometabolic activity on the $\mathrm{pH}$ buffering capacity of remediated soil (Steppe zone, Ukraine). Biology Bulletin, 42(10), 899-904.
Lovinska, V., Sytnyk, S., Kharytonov, M., Loza, I. (2016). Features of pine stands function in Dnieper North Steppe, Ukraine. The Journal Agriculture and Forestry, 62(1), 155-163.

Maltseva, I. A., Baranova, O. A. (2014). Algae of technogen ecotopes of iron-ore plant. Algology, 24(3), 350-353.

Pecharová, E., Martis, M., Kašparová I. (2011). Environmental approach to methods of regeneration of disturbed landscapes. Journal of Landscape Studies, 4(2), 71-80. 